purification (extraction as a salt into water from an organic solvent), which was suggested in Oxford by N.G. Heatley, had already been taken (unknown to him) in 1934 by Lewis Holt, a chemist at St Mary's Hospital whose work was never mentioned by Fleming. Moreover, the penicillin produced later in the United States for clinical use (benzylpenicillin) differed in its side-chain from the penicillin then being studied in Oxford.

The book also contains comments on another aspect of this question. After the clinical trials at Oxford in 1941 Florey decided that American help would be essential for the war-time production of penicillin in quantity. With the agreement of the Medical Research Council and financial support of the Rockefeller Foundation, he and Heatley went to the United States to try to interest the American pharmaceutical industry. Penicillin, then only produced in minute quantities, was far from easy to sell, but Heatley was invited to the Fermentation Division of the Northern Regional Research Laboratory in Peoria to help get a project started. He worked with A.J. Moyer, described in the book as "a fervent anti-British isolationist" with a "positive flair for making moulds do what was wanted". Moyer and Heatley had agreed on a joint publication, but the paper which eventually appeared was in Moyer's name alone. During this time the outlook for penicillin production was revolutionised by the American decision to add corn-steep liquor to the growth medium and to use deep fermentation, and these advances became the subject of American patents. British firms were understandably irked when they discovered that they were required to pay royalties to America to produce a substance that was essentially a British discovery. But equity and patent law may sometimes diverge. At the root of the problem was the fact that the official pre-War world in Britain was entirely unprepared for a situation of the kind that penicillin threw up. And there is, of course, another side to the matter. Without American help it is inconceivable that enough penicillin would have been produced, as it was, to treat all serious battle casualties, British and American, when D-day came in Europe.

The penultimate chapter of the book is headed "Palmam qui meruit ferat", a phrase used by Almroth Wright in a letter to The Times on 31 August 1942 firmly placing a laurel wreath on Fleming's brow. The nature of the publicity that followed can be attributed partly to Florey's refusal to talk to the press, partly to the welcome given to the press by Fleming and others at St Mary's Hospital and partly to the unwillingness or inability of popular writers to acquaint themselves with the facts in the scientific literature. One of these stories, written by a bacteriologist at St Mary's and more ludicrous than others only in the extent of its fabrication, attributed virtually all that had been done in Oxford to Fleming himself. The source of this myth is uncertain, but Gwyn Macfarlane remarks that behind Fleming were Almroth Wright "intensely ambitious for his department" and Lord Moran, Dean of St Mary's Hospital Medical School "Whose dearest wish was for its honour, glory, and financial security" and suspects that an efficient Public Relations Officer was active somewhere in the organisation. Fleming himself is said to have derived an impish glee from the more bizarre stories as he collected cuttings, a reaction that might have been understandable had he not been gaining worldwide gratitude from their publication.

Florey complained of this situation to Edward Mellanby who replied that it was ephemeral and of little consequence and that "in time even the public will realise that in the development of this story of penicillin, the thing that has mattered most has been the persistent and highly meritorious work of your laboratory". There is now now reason to think that the

\section{Olduvai record}

\section{J. Desmond Clark}

Olduvai Gorge: My Search for Early Man. By Mary Leakey. Pp. 181. (Collins: London, 1979.) £6.50.

EAST AFRICA remains unsurpassed in the wealth of discoveries and the understanding these provide about the biological and cultural evolution of our own species. It is no exaggeration to say that the very impressive record of hominid fossils and cultural remains in their palaeoenvironmental setting that has come from East Africa and the Horn over the past twenty years, has revolutionised our knowledge of human phylogeny. The hundreds of fossil hominid remains recovered, often remarkably complete and well preserved, and the circumstances of their preservation have made it possible to identify some of the behavioural adaptations that underlie the beginnings of tool-making and the ensuing intellectual development manifest in the increasing complexity of the tool-kits and the economic strategies that gave rise to them.

A very great deal of what is known today results from the lifetime devoted by Louis and Mary Leakey to their search for early man - a search which has completely vindicated Louis' claim, first made when he was an undergraduate at Cambridge in the $1920 \mathrm{~s}$, that a wealth of evidence awaited discovery in the deep sedimentary sequences of the Great Rift Valley. It was really the first full season's work in 1935 at the Olduvai Gorge in northern Tanzania, which was also Mary Leakey's publicity has ever affected the judgement of scientific bodies of any consequence, but its effect on the public has been far from ephemeral.

Gwyn Macfarlane finally summarises some of the qualities which combined to make Florey an outstanding figure: his great energy and enthusiasm for research; his skill as an experimenter and commitment to experiments that gave clearcut results; his judgement and sense of direction; and his complete intellectual integrity, never clouded by vanity. His colleagues who came to like and admire him will remember that behind a deep reserve there were kindness and consideration for their welfare. It is to be hoped that this well documented book will make his qualities and great contributions to science and medicine more widely known.

E.P Abraham is Professor of Chemical Pathology in the Sir William Dunn School of Pathology at the University of Oxford, UK.

introduction to fieldwork in the African Quaternary, that was the first demonstration of the correctness of Louis' conviction. It was also the first manifestation of his shrewdness - some would say his luck - in having concentrated on the Rift which, as can now be seen, is probably the most significant region in the world for preservation of the Plio-Pleistocene record that spans the emergence and early development of man the tool-maker.

The fossil, geological and cultural evidence is unique, both in its completeness and in the relatively minor disturbance that it has suffered. This has made it possible to reconstruct the changing climatic and ecological conditions under which hominid evolution took place, to find and excavate the activity places of the hominids, and to date all these events. In the 1930 s, there was no way of knowing how old the then earliest fossils and stone tools were. At that time Keith's 'guesstimate' of 200,000 to 400,000 years did not seem unreasonable to many and, indeed, most people then thought in terms of half a million or so years for the beginning of the Pleistocene. Now, K/Ar, uranium fission-track dating and the palaeomagnetic reversal chronology show that the earliest stone tools are about 2 million years old; that the earliest, well-known hominid (Australopithecus afarensis) is between 3 and 4 million years old; and that even earlier, but fragmentary, remains are present in the East African sedimentary record. From the 1960 s onwards, a number of interdisciplinary and international teams have been working in the East African and Ethiopian sections of the Rift and on the adjacent parts of the plateau for example, at Laetoli, Olduvai, Omo, East Turkana, Hadar, and on the 
Ethiopian Plateau. The discoveries and information that this work is producing are of paramount significance and there is every expectation that, as the research continues, an even greater wealth of material, detail and clarification will result.

Dr Mary Leakey's contribution to all this is both very substantial and outstanding in its importance. It was she who pioneered and introduced to Pleistocene prehistory the methods of excavation, recording and recovery that are common practice today. A meticulously careful and observant fieldworker, Mary Leakey found that activity areas were still preserved within the fine-grained sedimentary sequences in the East African Rift where she and Louis worked. She was also the first to demonstrate the existence of these early sites and to apply to them the methods used by archaeologists in the excavation of settlements of much more recent times. By exposing the whole, or large parts of an occupation area to give a complete visual perception of the relationships between all the imperishable residues - artefacts, bone waste, features, hominids, and so on - in their palaeotopographical setting, palaeoanthropologists now have the opportunity of making direct comparisons with the residues resulting from various accumulating and dispersing agencies geological, chemical, animal or human and therefore of developing explanatory models for early hominid behaviour.

Since 1959, when she found the first hominid cranium (Australopithecus boisel) in Olduvai Gorge, Mary Leakey has worked there almost continuously; and since 1968, she has made her permanent home at the Gorge. The scientific results of her work are recorded in the classic Volume 3 in the Olduvai Gorge Series (Olduvai Gorge: Excavation in Beds $I$ and $I I$, 1960-1963; Cambridge University Press, 1971) which is shortly to be followed by a volume on the discoveries in Beds III and IV and the later sediments. Obviously, such works are not the place in which to record some of the more personal events of everyday life at Olduvai - always exciting and packed with activity.

The present book is an attempt to make up for this by telling something of camp life at Olduvai and the way the work there has progressed through her own systematic fieldwork and that of the team of collaborators who have been working with her on the geology, palaeontology and chronology of the Olduvai sedimentary sequence that began two million years ago. For someone wishing for an overall appreciation of the setting in the Serengeti, a record of the main discoveries with something of their significance and an account of some of those involved with the author in the work at Olduvai, the book admittedly fills a need. It is divided into eight chapters, the first seven dealing with the early discovery of the Gorge; camp life; geology, dating and excavation methods;

\section{Sorry, for copyright reasons some images on this page may not be available online}

the stratigraphic sequence of sites in their geological setting; the search for the hominids; the nature of the stone artefact assemblages, with a very usefull illustrated glossary of terms; the associated animal remains; and the evolutionary changes which the Olduvai record shows that some of these underwent.

The book, however, will not entirely satisfy the reader who looks for a more personal account of the life and work at Olduvai - the problems, stresses, excitements, frustrations and successes of the author's life and search. Her interest in the natural setting, the vegetation and the animals is readily apparent but some readers might, for example, have appreciated a descrintion of the view from the camp dining room following the remark (page 23) that it is magnificent. Similarly, more might have been made of the opportunity to describe the Masai way of life. The layman would also, no doubt, have found it useful to have had more of the scientific names of the animals, and so on, explained in chapter 7 .

On the other hand, the description of the prehistoric living sites and stone tools well conveys the author's particular interest in this part of the work and describes the way in which a living site is laboriously uncovered. Also, some of the excitement and rewards of the work are conveyed by the account of the stone circle which portrays the earliest man-made structure yet known and which was found at the base of the more than 350 foot sedimentary sequence, and also by the description of the more enigmatic "pits"' on a later site. More space might have been given to an account of the butchery sites but prehistorians will find valuable the previously unpublished data on Beds III and IV and the later series of beds.

Regrettably, the hominid footprints found at Laetoli receive hardly more than passing mention and, even though Laetoli is a short way distant to the south of Olduvai, more space might surely have been devoted to this momentous discovery which provides proof of the bipedal nature of Pliocene man.

In the concluding chapter, Dr Leakey discusses the significance of the East African evidence and the great potential that exists there for increasing understanding of the ways of life of the earliest hominids. As she points out, the evidence coming from the African continent is today the most complete for this time period anywhere ir the world; this can, in part, be explained by the unique circumstances of preservation and the continuity of research there. The opportunities for fieldwork as well as the circumstances under which fossils were preserved and the possibilities of dating them have not been so good in the Asian tropics. It is, nevertheless, essential to know if an equally long record of hominid evolution also exists there; and it is to be hoped that the field studies now under way will provide at least part of the answer, through the kind of teamwork which has proved so successful at the Olduvai Gorge and which is revealed in this book.

Although the book does not really do justice either to the enthusiasm or the known achievements of its author, it does contain much of interest to all kinds of readers. It remains a record of more than forty years of unparallelled devotion to the search for early man.

J. Desmond Clark is Professor of Anthropology at the University of California at Berkeley. Professor Clark has known Mary Leakey since 1941 , and has worked with her many times since then. 